\title{
Erratum to: Particulate matters from diesel heavy duty trucks exhaust versus cigarettes emissions: a new educational antismoking instrument
}

Cinzia De Marco ${ }^{1 *}$, Ario Alberto Ruprecht ${ }^{1}$, Paolo Pozzi ${ }^{1}$, Elena Munarini ${ }^{1}$, Anna Chiara Ogliari ${ }^{1}$, Roberto Mazza ${ }^{2}$ and Roberto Boffi ${ }^{1}$

After publication of the original article [1] it was brought to our attention that the graph in figure two (here referred to as Fig. 1) contained an error in the intertitles. The corrected graph has been included in this erratum as Fig. 1. Please note that this error does not affect any conclusions drawn in the original article.

\section{Author details}

${ }^{1}$ Tobacco Control Unit, Fondazione IRCCS Istituto Nazionale dei Tumori, Milan, Italy. ${ }^{2}$ Patient Information Service, Fondazione IRCCS Istituto Nazionale dei Tumori, Milan, Italy.

Received: 2 February 2016 Accepted: 2 February 2016

Published online: 16 February 2016

\section{Reference}

1. De Marco C, Ruprecht AA, Pozzi P, Munarini E, Ogliari AC, Mazza R, et al. Particulate matters from diesel heavy duty trucks exhaust versus cigarettes emissions: a new educational antismoking instrument. Multidisciplinary Respiratory Medicine. 2016;11:2.

\footnotetext{
* Correspondence: cinzia.demarco@istitutotumori.mi.it

${ }^{1}$ Tobacco Control Unit, Fondazione IRCCS Istituto Nazionale dei Tumori, Milan, Italy
}

Submit your next manuscript to BioMed Central and we will help you at every step:

- We accept pre-submission inquiries

- Our selector tool helps you to find the most relevant journal

- We provide round the clock customer support

- Convenient online submission

- Thorough peer review

- Inclusion in PubMed and all major indexing services

- Maximum visibility for your research

Submit your manuscript at www.biomedcentral.com/submit

\section{Biomed Central}

\section{$\int$ Biomed Central}

(c) 2016 De Marco et al. Open Access This article is distributed under the terms of the Creative Commons Attribution 4.0 International License (http://creativecommons.org/licenses/by/4.0/), which permits unrestricted use, distribution, and reproduction in any medium, provided you give appropriate credit to the original author(s) and the source, provide a link to the Creative Commons license, and indicate if changes were made. The Creative Commons Public Domain Dedication waiver (http://creativecommons.org/publicdomain/zero/1.0/) applies to the data made available in this article, unless otherwise stated. 


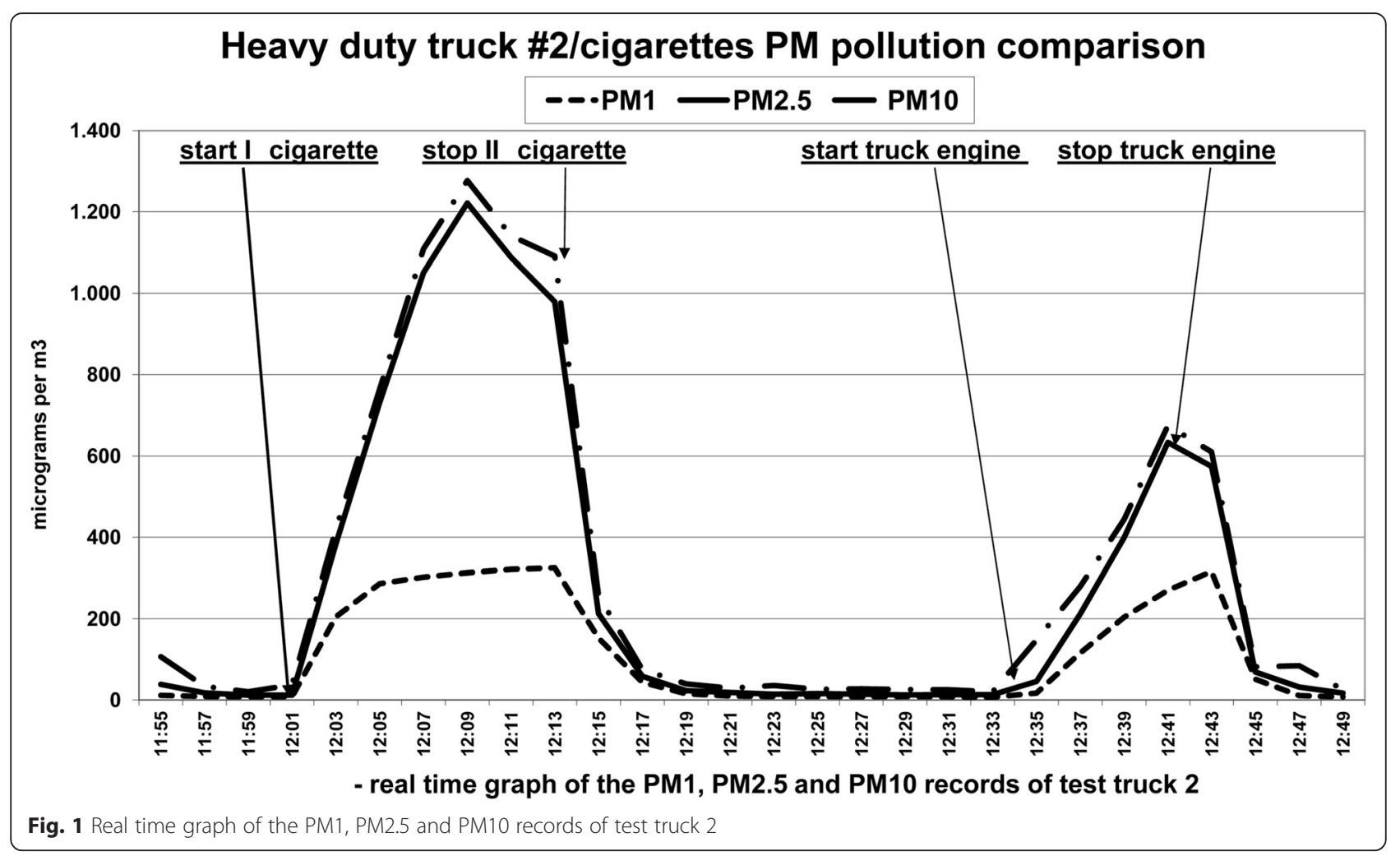

